\title{
Spatio-temporal variation of water quality and bio indicators of the Badulu Oya in Sri Lanka due to catchment disturbances
}

\author{
W.D.T.M. Gunawardhana ${ }^{1 *}$, J.M.C.K. Jayawardhana ${ }^{1}$, E.P.N. Udayakumara ${ }^{1}$ and S. Malavipathirana ${ }^{2}$ \\ ${ }^{I}$ Department of Natural Resources, Faculty of Applied Sciences, Sabaragamuwa University of Sri Lanka, Belihuloya. \\ ${ }^{2}$ Department of Physical Science and Technology, Faculty of Applied Sciences, Sabaragamuwa University of Sri Lanka, Belihuloya.
}

Revised: 28 August 2017; Accepted: 21 September 2017

\begin{abstract}
Safe and ample supply of freshwater is fundamental to humans and for the sustainability of ecosystem function. Therefore, impacts of catchment disturbances on surface water quality have been given special attention currently. The Badulu Oya sub-catchment of the Upper Mahaweli catchment area in Sri Lanka is one of the landscapes affected by intensive agricultural activities and urban development. This study was aimed at evaluating the spatial and temporal variation of water quality, stream physical habitat quality and macroinvertebrate bioindicators in the Badulu Oya catchment area in relation to disturbances due to agricultural and urban practices. Physicochemical water quality parameters and macroinvertebrate indices were evaluated at ten sampling sites in the Badulu Oya catchment area within a one year period. The results revealed that water quality variables such as electrical conductivity (EC), total solids (TS), total dissolved solids (TDS), dissolved oxygen (DO), alkalinity, nitrate- $\mathrm{N}\left(\mathrm{NO}_{3}-\mathrm{N}\right)$ and physical variables such as stream channel quality index (CQI) and riparian quality index (RQI) are significantly influenced by the degree of catchment disturbances. Among the macroinvertebrate indices tested, total abundance and family richness significantly varied with the degree of catchment disturbances. The findings of the present study revealed that the land use practices of Badulu Oya catchment result in significant impacts on stream ecological health. Similarly the study also revealed the prospect of using attributes such as water quality, physical habitat quality and macroinvertebrate bioindices for river health monitoring programmes.
\end{abstract}

Keywords: Agricultural impacts, macroinvertebrate indices, river catchments, river health, urban impacts.

\section{INTRODUCTION}

Aquatic ecosystems around the world are increasingly affected by anthropogenic impacts more specifically occurring in the respective catchment landscapes (Allan, 1995; Alam et al., 2006; Jayawardana et al., 2016). Alteration of land cover on the catchments of rivers and streams influences in-stream habitats, water quality and aquatic fauna in a number of ways. It has been reported that catchment alteration may impact stream ecological functions such as the dynamics of riverine carbon cycle and food web structure and functions (Webster et al., 1983; Gregory et al., 1991). Removal of natural vegetation in catchments may contribute to increase the area of impervious surfaces influencing the evapotranspiration and infiltration and also to alter the natural flow regimes (Changnon \& Demissie, 1996). Subsequently, these changes may increase the sediment inputs to streams by erosion and alteration of substratum characteristics and channel morphology, thus reducing aquatic species diversity (Lake et al., 1985; Bunn et al., 1986). Altered catchment hydrology and land use can influence inputs of inorganic nutrients from terrestrial sources and enhance in-stream primary productivity resulting in changes of the aquatic trophic structure and benthic communities (Death \& Winterbourn, 1995).

Agricultural production depends heavily on intensive agricultural practices resulting in negative impacts on

*Corresponding author (madhumanee@gmail.com; (iD https://orcid.org/0000-0002-7711-6410)

This article is published under the Creative Commons CC-BY-ND License (http://creativecommons.org/licenses/by-nd/4.0/). This license permits use, distribution and reproduction, commercial and non-commercial, provided that the original work is properly cited and is not changed anyway. 
the environment. The major rivers of Sri Lanka originate from the central hills and their catchment areas are subjected to a variety of land use changes as a result of development activities and intensive agricultural practices (Watawala et al., 2010). The Mahaweli River catchment is the largest catchment in Sri Lanka, which provides water to the Mahaweli River and the major reservoirs built along the river. This catchment is considered very important to the Sri Lankan economy as it also provides water needed to generate $55 \%$ of the electricity requirement of the country, and to irrigate a large extent of paddy and other field crops (Bandara \& Thiruchelvam, 2008). Badulu Oya originates from the Namunukula mountain range and is one of the main tributaries of the Mahaweli River. The catchment of this river has also been subjected to various land use changes during the last few decades. Previously forested catchment areas have been continuously cleared and converted into agricultural land and urban settlements. Evaluation of such land conversion impacts on stream ecological integrity is important for taking decisions in catchment management and for the adoption of better management practices. Effect of such land use changes on the ecological integrity of streams have to be assessed through holistic approaches taking into account physical, chemical and biological criteria.

In many countries in temperate regions of the world, macroinvertebrate bioindicators are commonly used to assess the stream health in conjunction with water quality data (Hilsenhoff, 1987; Muirhead-Thompson, 1987; Plafkin et al., 1989; Johnson et al., 1993; Lenat, 1993; Jayawardana et al., 2006a; 2006b; 2010; Jayawardana \& Westbrooke, 2010). These bioindices are very effective for the assessment of river health since they reflect longterm environmental impacts effectively and efficiently compared to physico-chemical parameters. Such indices are also important for the accurate assessment of the status of river health and development of mechanisms for catchment management in Sri Lanka. The lack of baseline data on responses of aquatic bioindicators to land use impacts is one of the limitations of application of bioindices in river health monitoring programmes in Sri Lanka. Therefore, this study was conducted with the aim of evaluating the spatial and temporal variation of water quality and macroinvertebrate bioindicators in Badulu Oya catchment area with respect to agricultural and other land use disturbances.

\section{METHODOLOGY}

\section{Study area}

Badulu Oya catchment is one of the sub-catchments of the Upper Mahaweli catchment area, which extends $318 \mathrm{~km}^{2}$. It is located in latitudes $7^{\circ} 12^{\prime} 43.2^{\prime \prime} \mathrm{N}$ and longitudes $80^{\circ} 59^{\prime} 50.63^{\prime \prime} \mathrm{E}$ within the Wet Zone of Sri Lanka. The study region receives an annual average rainfall of $2000 \mathrm{~mm}$. The Badulu Oya catchment receives rains during the wet season (October to March) and dry weather prevails in the catchment from April to September. The landscape of the catchment area varies from undulating, rolling topography to hilly, steeply dissected mountain terrain. The predominant soil type in the area is red yellow podzolic (De Alwis \& Panabokke, 1972). The landscape of the catchment was covered with natural vegetation until the early $19^{\text {th }}$ century (Wickramagamage, 1988). Subsequently the forest cover of the catchment area has been greatly reduced due to the expansion of agricultural lands and urban development activities. Presently fragmented patches of natural forest are present in the catchment and the rest of the area is covered by tea, vegetable and paddy cultivated lands, and urban settlements. Vegetable crops are predominantly grown in the Badulu Oya catchment area during the dry season and paddy is cultivated during the rainy season.

Ten locations in $2^{\text {nd }}$ or $3^{\text {rd }}$ order tributaries of Badulu Oya were selected as sampling sites for the study (Figure 1). The catchment area land cover patterns were analysed using Landsat TM satellite images (Data or acquisition $10^{\text {th }}$ March 2011, with $30 \mathrm{~m} \times 30 \mathrm{~m}$ resolution), 1:50000 topographic maps (Department of Survey, Sri Lanka), Google Earth satellite images and field observations. The land cover of micro-catchments of the selected sampling tributaries ranged from pristine undisturbed natural forests to landscapes, which have been severely altered by deforestation, agriculture and urban settlements. The selected sampling sites were classified based on the extent of agricultural, urban and forested land cover in the respective micro-catchments of the sampling tributaries. The micro-catchments, which have less than $20 \%$ forest cover were classified as highly disturbed sites; $20-35 \%$ forest cover as medium disturbed sites and more than $35 \%$ forest cover as less disturbed sites/ reference sites (Table 1).

\section{Riparian and channel physical habitat quality estimation}

Riparian quality index (RQI) and channel physical habitat quality index (CQI) were developed to assess the quality of riparian zone of streams and the channel habitat quality, respectively. RQI and CQI for the sampling reaches were developed using the criteria of rapid bio assessment protocols for use in streams and wadeable rivers (Barbour et al., 1999). For the development of RQI, attributes such as the extent of lateral extension of forest 


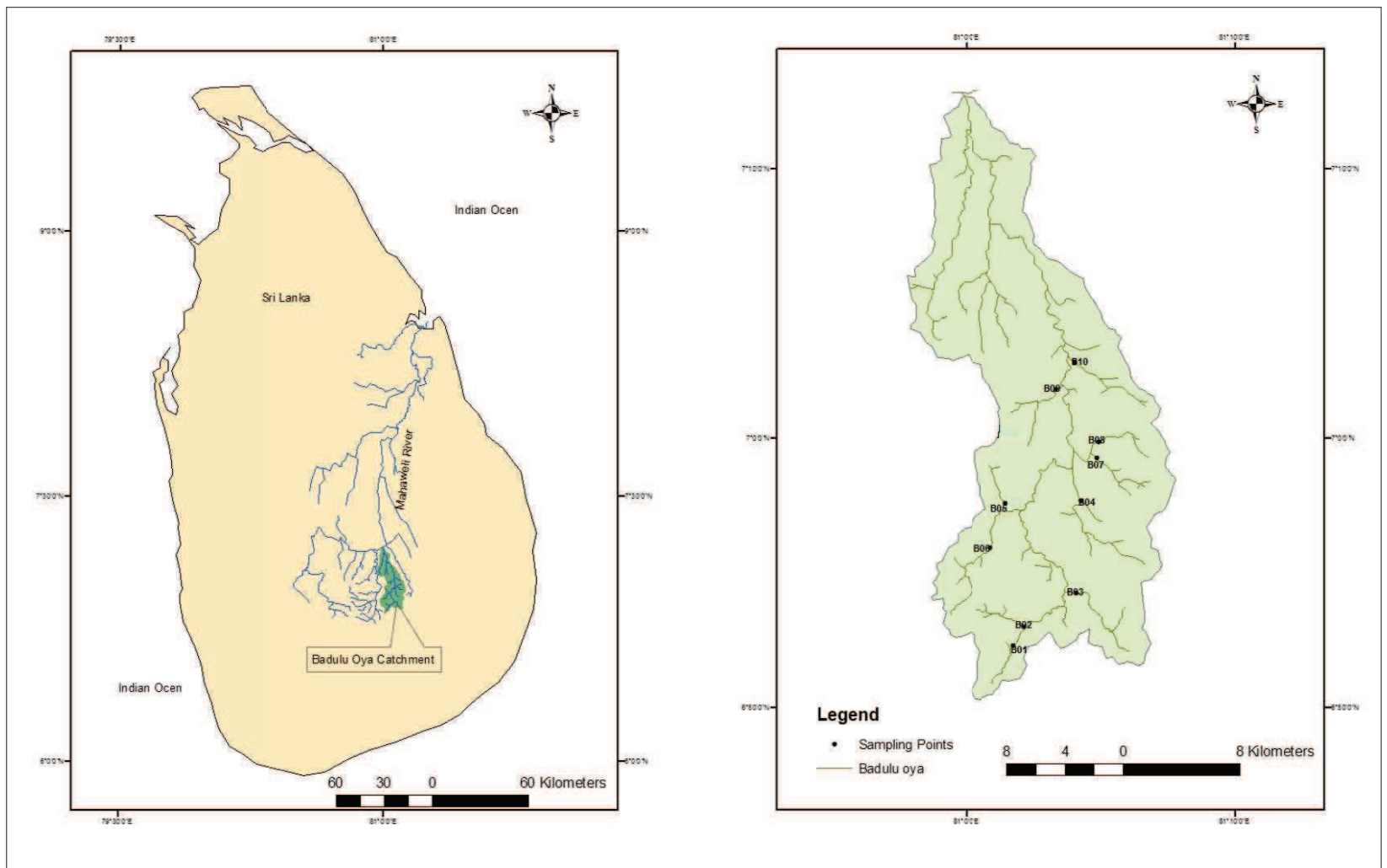

Figure 1: Sampling locations in Badulu Oya

Table 1: Sampling reaches of Badulu Oya catchment area

\begin{tabular}{lcl}
\hline Sampling reach & Altitude $(\mathrm{m})$ & Remarks \\
\hline B01 - Kumbalwela & 982 & Low level of catchment disturbances/ reference site \\
B02 - Helahalpe & 948 & Highly disturbed area with agricultural activities \\
B03 - Demodara & 865 & Medium scale catchment disturbances. Mainly tea cultivated area \\
B04 - Wewahinna & 657 & Low level of catchment disturbances/ reference site \\
B05 - Moretota & 975 & Highly disturbed area with agricultural activities \\
B06 - Haliela & 744 & Highly disturbed area with agricultural and urban activities \\
B07 - Sirimalgoda Oya & 710 & Highly disturbed area with agricultural activities \\
B08 - Maramgaha Oya & 695 & Highly disturbed area with agricultural activities \\
B09 - Ambagaha Oya & 410 & Medium scale catchment disturbances by agricultural activities \\
B10 - Pussallawa & 409 & Low level of catchment disturbances/ reference site \\
\hline
\end{tabular}

cover on either side of the river, riparian composition (woody trees/grasses/ bare) and riparian continuity were assessed along a $300 \mathrm{~m}$ stream segment upstream from the sampling site. CQI was developed for each sampling reach using the primary channel characteristics (channel dominant substrate, water velocity, embeddedness) and secondary channel characteristics (velocity/depth regimes, degree of bank/channel alterations, sediment deposition, riffle characteristics, condition of banks, and canopy cover).

Water quality and macroinvertebrate sampling and analysis

Water samples were collected at monthly intervals from 10 sampling locations covering 10 sub-catchments from 
August 2014 to July 2015. pH, electrical conductivity (EC), temperature and dissolved oxygen (DO) were measured in situ using a portable multi parameter (HachMM 156). In addition, physical and hydrological data of the sampling reaches such as water flow, embededness, and substrate characters were also recorded. Water flow was measured using a hand-held flow meter (5" to 15 " expandable Global Water Flow Probe) and substrate characters and embededness were visually estimated (Platts et al., 1983; Fitzpatrick et al., 1998). Duplicate water samples were collected from each sampling location and brought to the laboratory using $1.5 \mathrm{~L}$ sampling bottles under cold conditions for analysis. For the calculation of total solids (TS), $25 \mathrm{~mL}$ of samples were dried at $105{ }^{\circ} \mathrm{C}$ and the residue weight was taken. Total suspended solids (TSS) was measured after filtering a sample using a $0.45 \mu \mathrm{m}$ filter paper and residue weight was taken after drying at $105^{\circ} \mathrm{C}$. The difference between TS and TSS was calculated as total dissolved solids (TDS). $\mathrm{NO}_{2}-\mathrm{N}, \mathrm{NO}_{3}-\mathrm{N}, \mathrm{PO}_{4}{ }^{3-}, \mathrm{SO}_{4}{ }^{2-}$, and $\mathrm{NH}_{3}-\mathrm{N}$ were measured in the laboratory using a Hach DR 2700 spectrophotometer. Biochemical oxygen demand $\left(\mathrm{BOD}_{5}\right)$ was measured after incubating a water sample for $5 \mathrm{~d}$ using Winkler's method. All analyses were conducted following APHA (2005) procedures. Ephilithic biomass $\left(\mathrm{g} / \mathrm{m}^{2}\right)$ was determined following the method adopted by Sponseller et al. (2001). Total coliform bacteria and faecal coliform bacteria were also measured in collected water samples adopting the US Environmental Protection Agency methodology (USEPA, 1978).

Macroinvertebrate samples were collected from study stream reaches (ten locations) using a surber sampler with a sample area of $12 " \times 12$ " at 3 month intervals covering the dry and rainy period of the catchment. Five replicate samples were collected from each sampling location. Macroinvertebrates were sorted and preserved in $70 \%$ alcohol and identified up to family level in the laboratory using identification guides (Pinder \& Brinkhurst, 1994; Cranston, 1996; Dean \& Suter, 1996; Smith, 1996; CSIRO, 1999; Gooderham \& Tsyrlin, 2002; Mendis \& Fernando, 2002).

Macroinvertebrate total abundance, family richness, percentage EPT taxa (ephemeroptera: plecoptera: trichoptera), percentage chironomids and Shannon diversity index (SDI) were calculated using macroinvertebrate data. Taxa richness and percentage EPT were calculated because they are universally used macroinvertebrate metrics. These metrics are easily calculated and track water quality changes effectively (Wallace et al., 1996; Karr \& Chu, 1999). Percentages of chironomidae were also estimated at the sites since they are indicators of the stress caused by pollution (Lencioni et al., 2012). Information from a number of sources was used to partition the invertebrate fauna into 5 major feeding categories, viz. shredders, collectors, predators, grazers and filter feeders (Merritt et al., 1984; Hauer \& Lamberti, 1996; Gooderham \& Tsyrlin, 2002).

\section{Analysis of data}

Principal component analysis (PCA) was conducted to explore the patterns of variation of the sites based on stream physical habitat quality, water quality and macroinvertebrate indices. Stream physical habitat quality, water quality data and macroinvertebrate indices were used as variable inputs for PCA. Since the input variables for PCA had different magnitudes and scales of measurements the data were standardised to produce a normal distribution of all variables. From the standardised correlation matrix of the data the initial factor solutions were extracted by multivariate principal components extraction. Components loading (correlation coefficients), which measure the degree of closeness between the variables and the principal components were also estimated. The most significant variables in the components represented by high loadings were taken into consideration for evaluation of the components (Mazlum et al., 1999). Multivariate analysis was conducted using PRIMER-7 software (Plymouth Marine Laboratory, Plymouth, UK).

Two-way analysis of variance (ANOVA) was conducted to evaluate the effect of land cover disturbance and seasonal impacts on stream water quality and macroinvertebrate indices. The degree of catchment disturbances (high: medium: low) and the season (dry and wet) were considered as main factors in the analysis. Data were checked for normality and homogeneity of variance before the analysis, and the data were log or square root transformed as necessary to meet the assumptions of linear models. Homogeneity of variance was tested with Levene's test, and normality of residuals was assessed from normal probability plots. The significant differences among sites and seasons were expressed at 0.05 significant level $(\mathrm{p} \leq 0.05)$. All analyses were conducted using SPSS statistical software (IBM SPSS Statistics for Windows, Version 20.0 Armonk, NY: IBM Corp) and Microsoft Excel 2007.

\section{RESULTS AND DISCUSSION}

\section{Multivariate analysis}

PCA of the physical habitat, water quality and macroinvertebrate indices in response to catchment scale 
land cover is depicted in Figure 2. The results of the PCA could be used to interpret the underlying trends of variation of stream water quality, physical habitat quality and macroinvertebrate indices in the Badulu Oya with respect to catchment disturbance.

The first five principal axes of PCA represented $69 \%$ of the data variability. Vector loading to the principal component axis indicated that $\mathrm{SDI}, \mathrm{NO}_{2}-\mathrm{N}$, family richness, RQI and CQI are highly associated with the PC1 axis. Conductivity, TDS, $\mathrm{SO}_{4}^{2-}$, grazers and collectors were associated with PC2. There was a separation of sites along the $\mathrm{PC} 1$ axis based on the levels of disturbance of the catchments. Sites associated with a high percentage forest cover at the catchment were grouped together in the positive side of the PC1 and the sites with low percentage forest cover in the negative side of the axis. SDI, family richness, RQI and CQI were associated with high percentage forest cover in the catchment while $\mathrm{NO}_{2}-\mathrm{N}, \mathrm{NO}_{3}-\mathrm{N}, \mathrm{TSS}, \mathrm{PO}_{4}{ }^{3-}$ and percentage chironomidae were associated with highly disturbed sites. The results of the PCA indicate a pronounced impact to the stream ecological health exerted by the catchment disturbance.
The spatial and temporal variations of water quality in highly and less disturbed sites were tested using two-way ANOVA. The averages and ranges of the selected water quality variables reported at sampling sites during the sampling period are given in Table 2. Many of the water quality parameters tested were within limits of ambient water quality standards for inland waters Sri Lanka (CEA, 2001) except TSS, $\mathrm{PO}_{4}^{3-}$ and total and faecal coliform levels.

The results of two-way ANOVA indicated a significant $(p<0.05)$ variation of some water quality parameters between seasons and the sites associated with varying degree of catchment disturbances (Table 3). Among the water quality variables tested, temperature is a vital factor for the growth and development of many aquatic species and for the function of all biological and biochemical reactions in the water. The temperature of the stream water can be affected by the level of solar radiation reaching the stream channel (Beschta \&Taylor, 1988; Rutherford et al., 1997). According to the results of the present study, average stream temperature varied from 21 to $26^{\circ} \mathrm{C}$ among sampling sites. Results of the

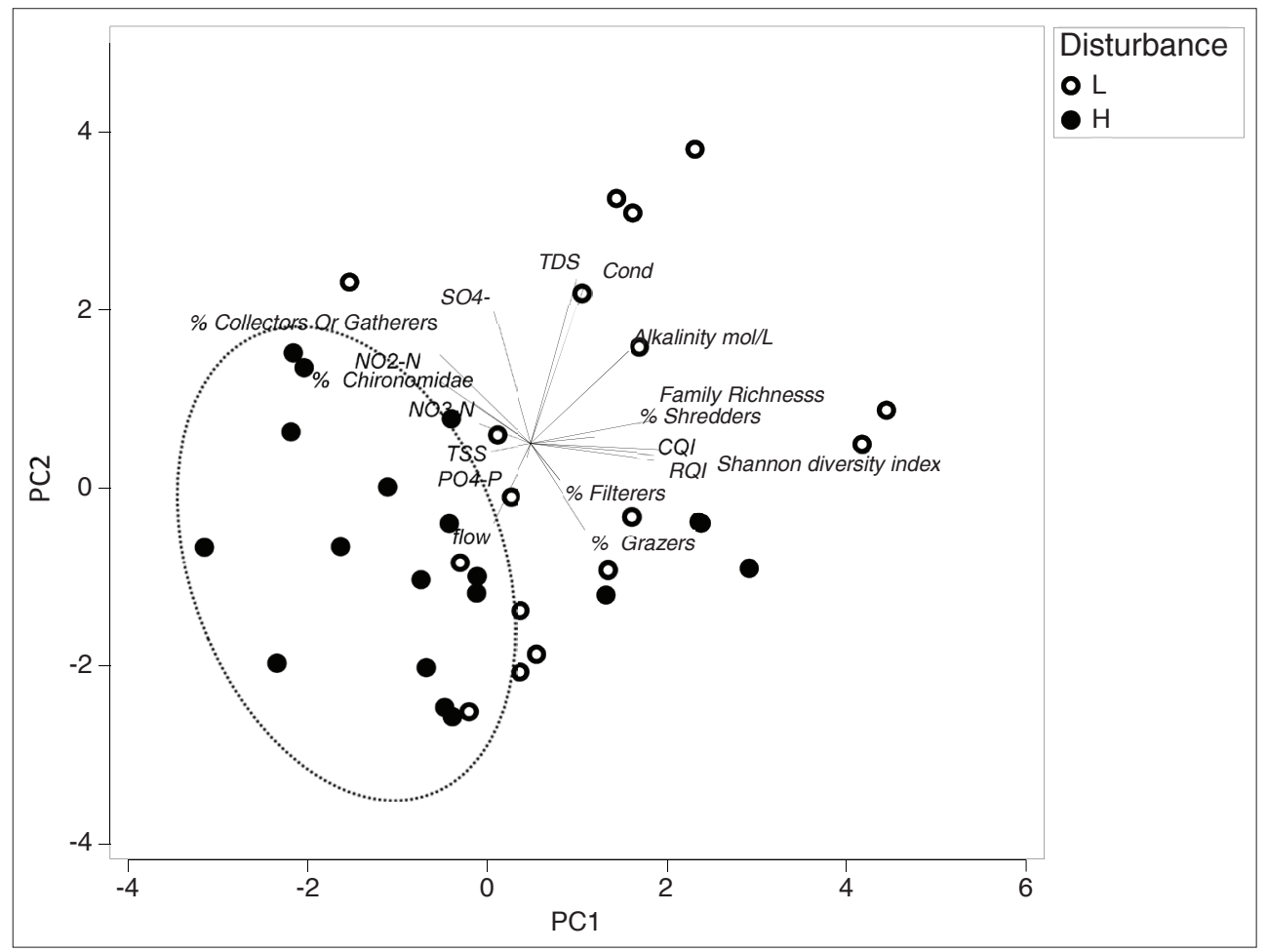

Figure 2: PCA plot indicating site variation based on stream physical habitat, water quality and macroinvertebrate bioindices (two letters in the legend indicate level of disturbed land cover based on the percentage forest cover at catchment scale $\mathrm{L}=$ low disturbed sites; $\mathrm{H}=$ highly disturbed sites) 


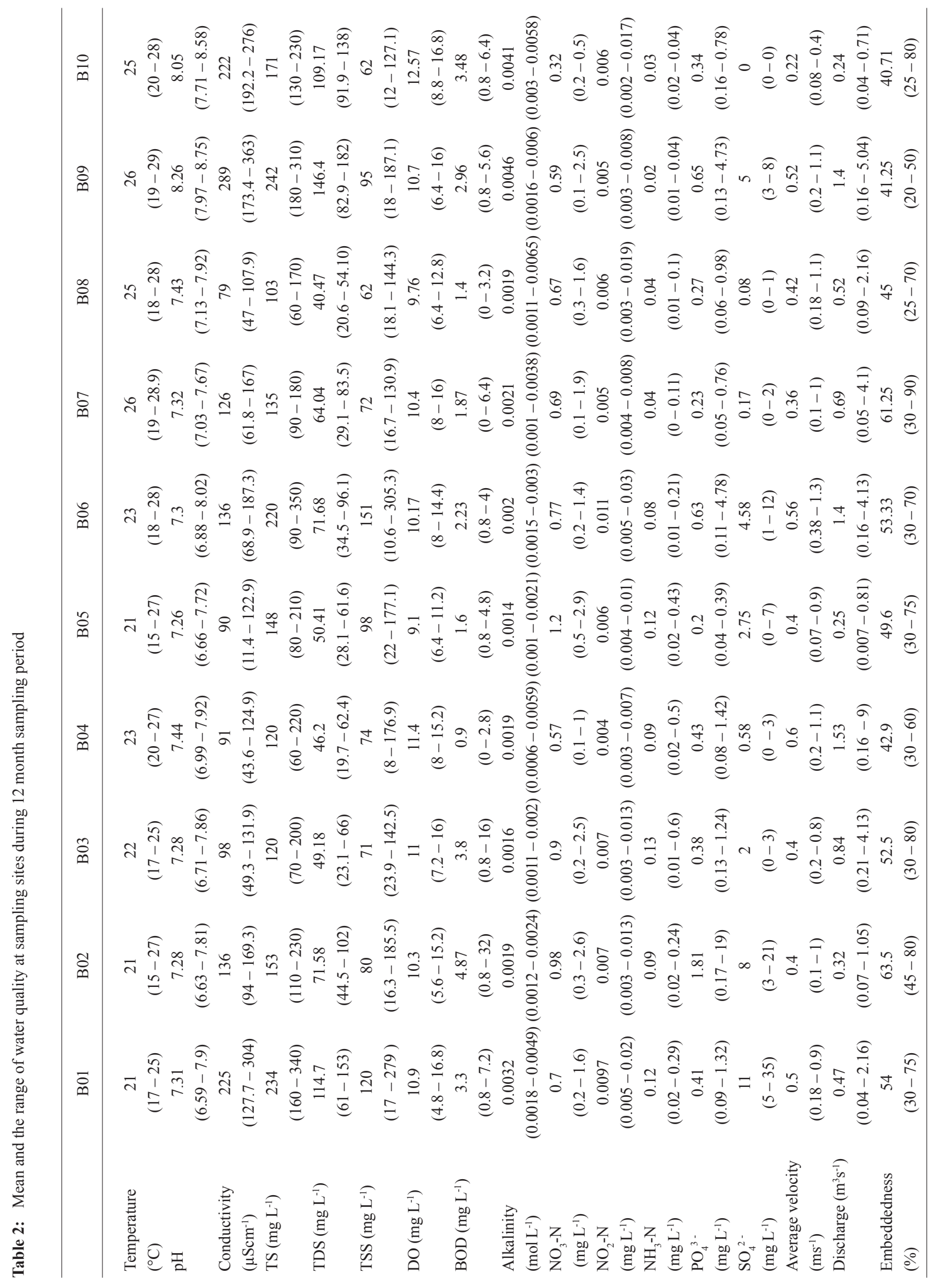




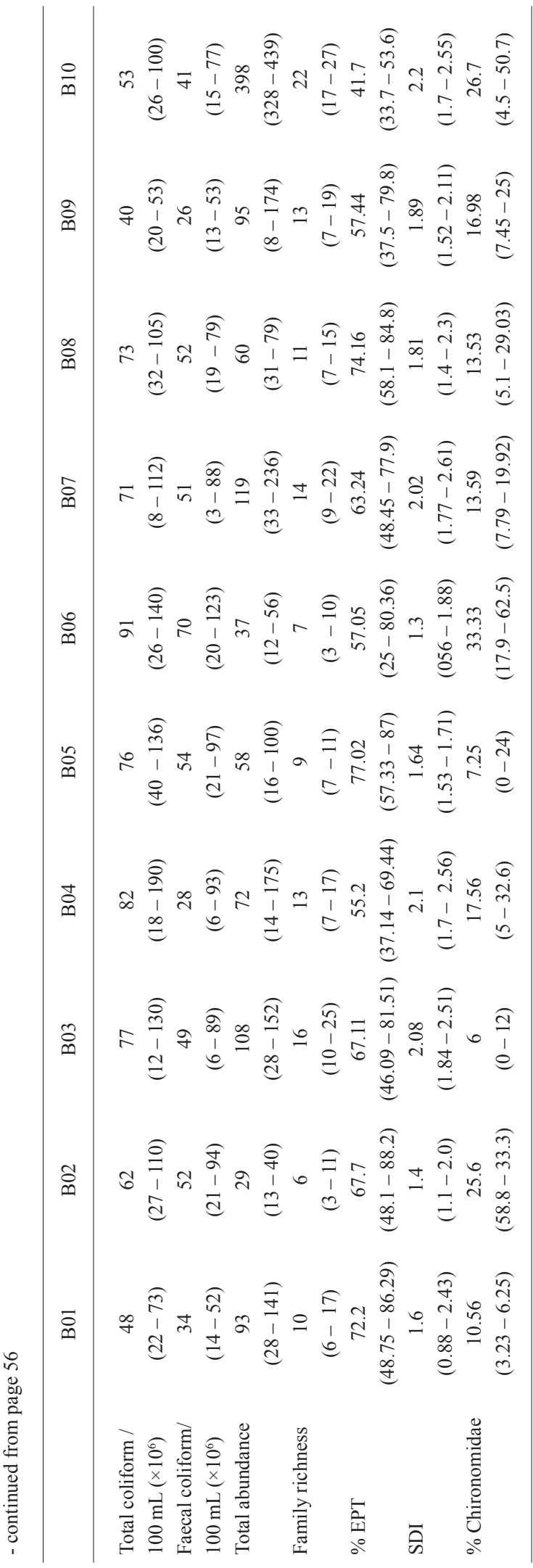

two-way ANOVA indicated significant $(\mathrm{p}<0.05)$ variation of average stream temperature between the two seasons but with no significant differences among sites associated with micro-catchments with varying levels of land disturbances (Table 3). Sri Lanka is a tropical island with no marked seasonal changes of temperature during the year as in many other temperate countries. The Badulu Oya catchment receives comparatively high rainfall during the wet season than in the dry season. It is evident from the results of the present study that the significant seasonal temperature variations of the study locations could be related to dry and wet seasons of the catchment.

Among the other water quality variables tested in the present study, EC, TS, TDS, TSS, DO, alkalinity and $\mathrm{NO}_{3}-\mathrm{N}$ were significantly influenced by the seasonal impacts and the degree of catchment disturbances. The EC of sampling sites ranged from 79.31 to 289.2 $\mu \mathrm{S} \mathrm{cm} \mathrm{cm}^{-1}$. Water EC significantly increased $(\mathrm{p}<0.05)$ during the dry period in comparison to the wet season and in sites associated with highly disturbed landscapes (Table 3 and Figure 3). TSS values varied between 62 to $151 \mathrm{mgL}^{-1}$ among sampling sites, and in many sites these values exceeded the ambient water quality standards for fish and aquatic life in inland waters Sri Lanka (CEA, 2001). It has been observed that in the given catchment most of the soil preparation activities for vegetable cultivation are conducted during the dry period. Especially irrigation return flow, which carries fertiliser, dissolved ions and soil particles coupled with low flow during the dry period may have contributed to the observed water quality variables in disturbed sites. Land degradation and water quality deterioration due to soil erosion by unplanned agricultural activities carried out in the Mahaweli catchment is also reported by many authors (Dharmarathne et al., 2008; Gunawardena et al., 2010; Hewawasam, 2010).

$\mathrm{NO}_{3}-\mathrm{N}$ levels in sampling sites varied between 0.1 to $2.9 \mathrm{mgL}^{-1}$ and it has been significantly influenced $(\mathrm{p}<0.05)$ by land cover disturbances at the catchment (Table 3 and Figures 3 and 5). Similar results were reported by many authors that the land cover at the catchment scale is a good predictor of in-stream nutrient concentration, particularly nitrate (Omernik, 1977; Close \& Davies-Colley, 1990; Johnson et al., 1997). It has been reported that the sediment input to streams resulting from soil erosion carries more nitrate and phosphate than that of in the dissolved fraction in water (Waters, 1995; Amarathunga et al., 2013). Heavy sediment loads 
carried with runoff from vegetable cultivated lands may have increased the nutrient levels in the stream water in disturbed landscapes. There was also an increase of $\mathrm{NO}_{2}-\mathrm{N}, \mathrm{NH}_{3}-\mathrm{N}$ and $\mathrm{SO}_{4}{ }^{2-}$ levels in sites associated with highly disturbed catchments but these variations were not significant (Figure 3). It has been reported by many authors that nitrites, ammonia containing compounds and organic loads contaminate waterways through wastewater discharge from urban areas (Allan, 1995). It can be expected that the waste from urban settlements in the catchment may have also contributed to such results. The microbiological quality of the water in study sites indicated elevated total and faecal coliform bacteria levels, which exceeded the proposed ambient water quality standards (total coliform $<20000$ colonies /100 mL, faecal coliform; $250-600$ colonies $/ 100 \mathrm{~mL}$ ) for fish and aquatic life in inland waters Sri Lanka (CEA, 2001) (Table 3). Two-way ANOVA results indicated a significant $(\mathrm{p}<0.05)$ variation of faecal coliform levels between the two seasons and among sites associated with micro-catchments with varying levels of land disturbances. The amount of faecal coliforms in the river water reflects the levels of sewage contamination of the river (Gregory \& Fric, 2000; Ecology's Water Quality Program, 2005). The elevated levels of faecal coliforms reported in highly disturbed sites in the Badulu Oya may have resulted from sewage input from urban areas and human settlements in the catchment.

Table 3: Results of main factors and their interaction for the tested water quality variables in the two-way ANOVA ( $\mathrm{p}$ values)

\begin{tabular}{|c|c|c|c|}
\hline Parameter & $\begin{array}{c}\text { Degree of catchment } \\
\text { disturbances (Cat_Disturb) }\end{array}$ & Seasonal effect & Cat_Disturb*Season \\
\hline Temperature & 0.611 & $0.000 *$ & 0.822 \\
\hline $\mathrm{pH}$ & $0.016^{*}$ & 0.159 & 0.691 \\
\hline Conductivity & $0.000^{*}$ & $0.046^{*}$ & 0.719 \\
\hline TS & $0.000^{*}$ & 0.720 & 0.960 \\
\hline TDS & $0.000 *$ & $0.004 *$ & 0.769 \\
\hline TSS & 0.088 & $0.000 *$ & 0.991 \\
\hline DO & $0.022 *$ & $0.000^{*}$ & 0.081 \\
\hline $\mathrm{BOD}_{5}$ & 0.119 & 0.626 & 0.756 \\
\hline Alkalinity & $0.000 *$ & $0.001 *$ & 0.393 \\
\hline $\mathrm{NO}_{3}^{-} \mathrm{N}$ & $0.041^{*}$ & 0.066 & 0.251 \\
\hline $\mathrm{NO}_{2}^{-} \mathrm{N}$ & 0.338 & 0.478 & 0.937 \\
\hline $\mathrm{NH}_{3}^{-} \mathrm{N}$ & 0.846 & 0.135 & 0.544 \\
\hline $\mathrm{PO}_{4}^{3-}$ & 0.930 & 0.252 & 0.725 \\
\hline $\mathrm{SO}_{4}^{2-}$ & 0.157 & 0.576 & 0.418 \\
\hline Stream velocity & 0.233 & $0.000^{*}$ & 0.237 \\
\hline Stream discharge & $0.003 *$ & $0.000 *$ & 0.338 \\
\hline Embeddedness & 0.050 & 0.045 & 0.378 \\
\hline Ephilithic biomass & $0.050 *$ & $0.035^{*}$ & 0.509 \\
\hline Total coliform & 0.588 & $0.000 *$ & 0.895 \\
\hline Faecal coliform & $0.000 *$ & $0.014 *$ & 0.879 \\
\hline Total abundance & $0.001 *$ & 0.103 & 0.856 \\
\hline Family richness & $0.024 *$ & 0.006 & 0.907 \\
\hline Shannon diversity index & 0.167 & 0.047 & 0.628 \\
\hline$\%$ ЕРТ & 0.108 & 0.860 & 0.827 \\
\hline$\%$ Chironomidae & $0.044 *$ & 0.504 & 0.862 \\
\hline$\%$ Grazers & 0.488 & $0.010^{*}$ & 0.120 \\
\hline$\%$ Shradders & $0.024 *$ & 0.315 & 0.376 \\
\hline$\%$ Collectors & 0.349 & $0.041^{*}$ & 0.136 \\
\hline$\%$ Filter feeders & 0.451 & 0.288 & 0.780 \\
\hline$\%$ Predators & 0.675 & 0.496 & 0.879 \\
\hline
\end{tabular}

* indicate significant $\mathrm{p}$ values at 0.05 level 

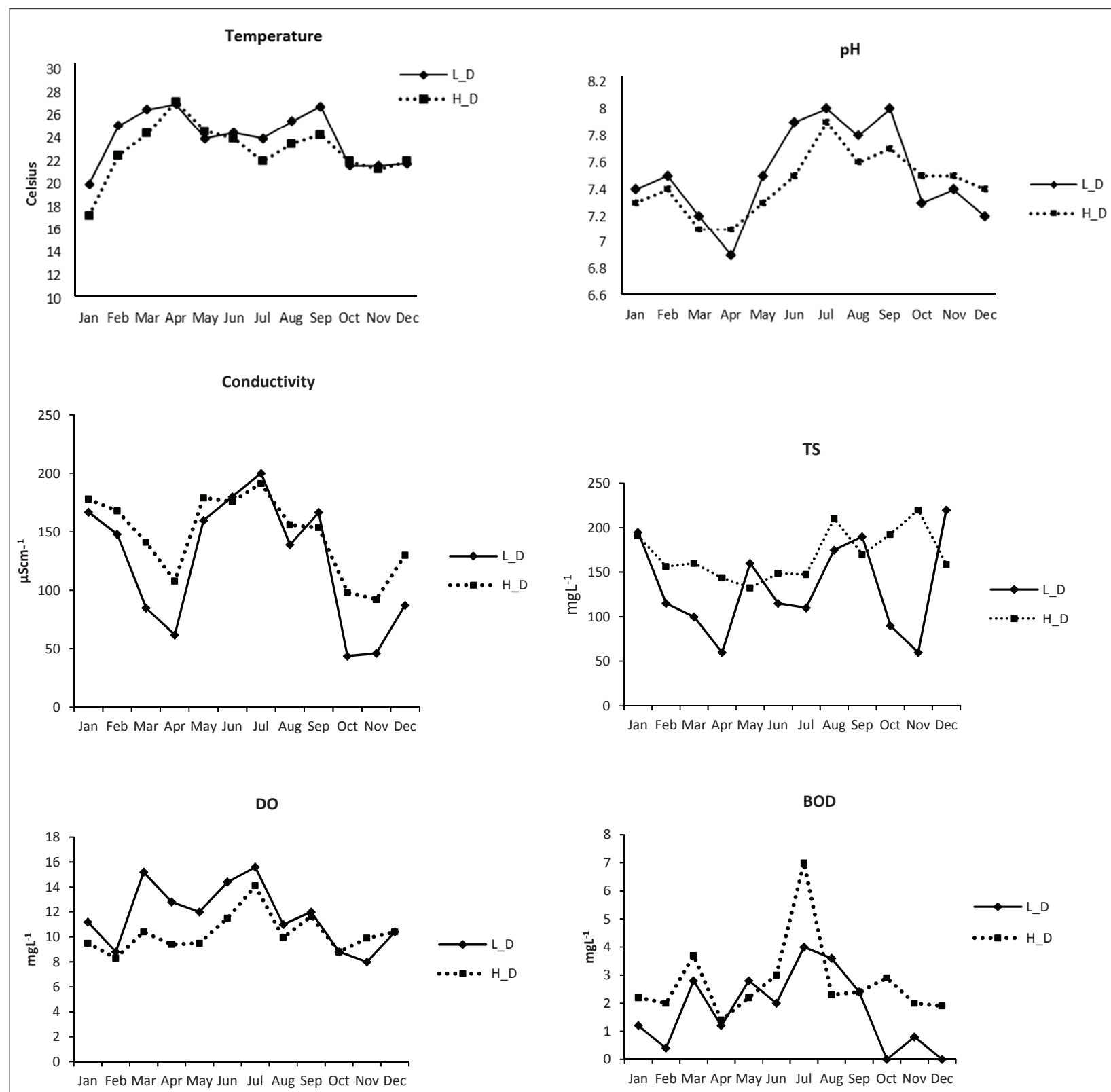

TDS

TSS
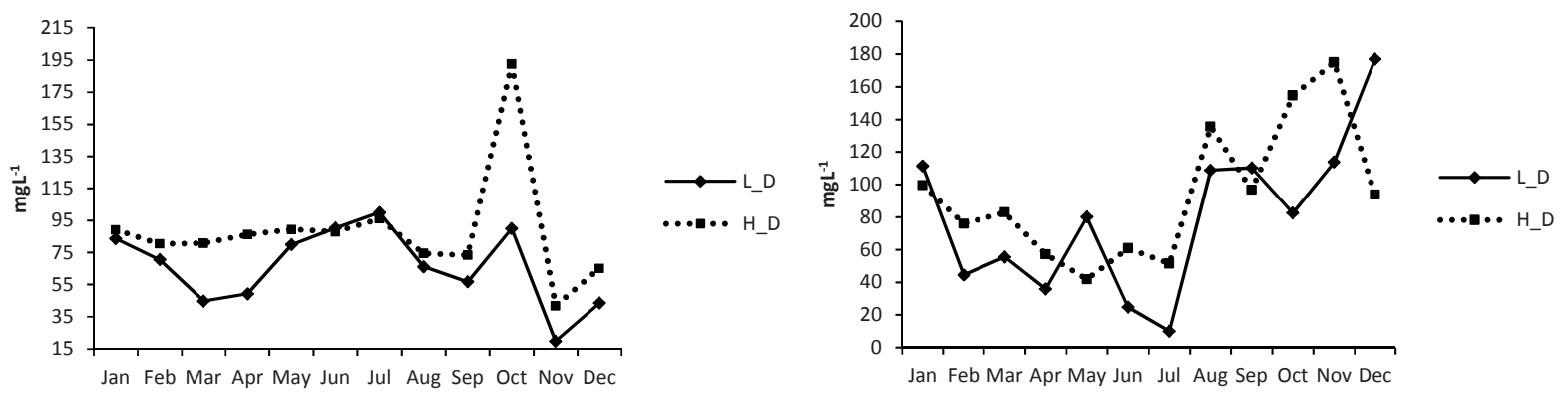

Continued - 
- continued from page 59
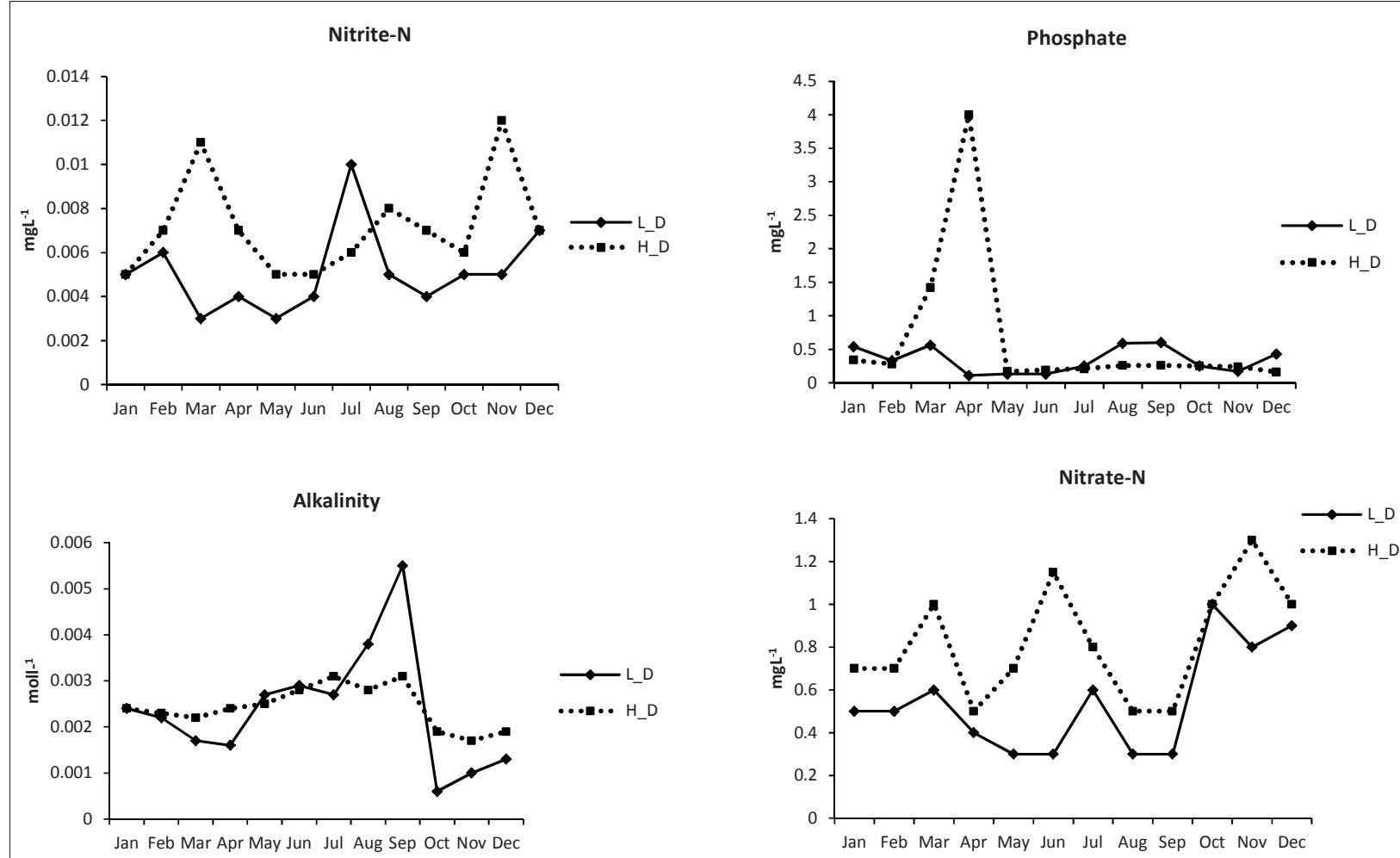

Sulphate
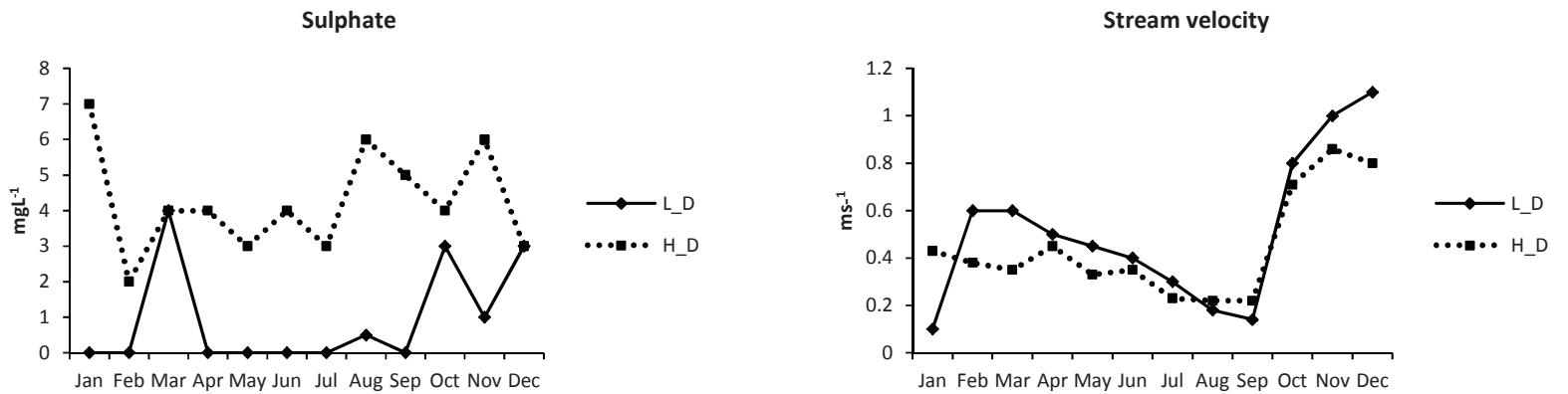

Ephilithic biomasss
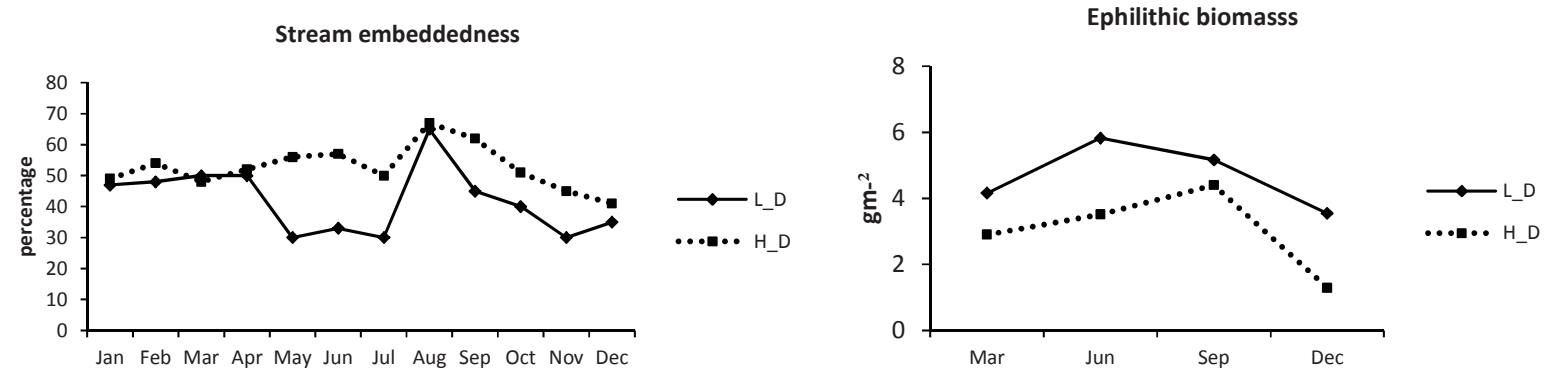

Figure 3: Monthly average water quality variation in sites associated with high (H_D) and low (L_D) catchment disturbances at entire catchment area 
RQI reflect the relative healthiness of the riparian vegetation in terms of quality of vegetation structure (Tánago \& Jalón, 2011). In the present study RQI scores ranged from 3 to 17 and high scores were recorded in less disturbed sites. PCA results also indicated that RQI is associated with sites with high percentage forest cover in the catchment. Human induced activities such as agriculture can have a significant impact on the riparian quality (Aguiar \& Ferreira, 2005). In many sites of the study, encroachment of banks of the streams by cultivated lands was evident and the riparian vegetation is completely cleared or fragmented. Lack of riparian cover along the river in agricultural and urban areas may have contributed to the higher inputs of contaminants in stream water through runoff.

Table 4: Macroinvertebrate taxa recorded in sampling sites during wet and dry seasons (+ present; - absent)

\begin{tabular}{|c|c|c|c|c|c|c|c|c|c|c|c|c|c|c|c|c|c|c|c|c|c|}
\hline \multirow[b]{2}{*}{ Order } & \multirow[b]{2}{*}{ Family } & \multicolumn{11}{|c|}{ Dry season } & \multicolumn{9}{|c|}{ Wet season } \\
\hline & & B01 & B02 & B03 & B04 & B05 & B06 & B07 & B08 & B09 & $\mathrm{B} 10$ & B01 & B02 & B03 & B04 & B05 & B06 & B07 & B08 & B09 & $\mathrm{B} 10$ \\
\hline \multirow[t]{3}{*}{ Ephemeroptera } & Baetidae & + & + & + & + & + & + & + & + & + & + & + & + & + & + & + & + & + & + & + & + \\
\hline & Caenidae & + & - & + & + & - & - & + & + & + & + & - & - & + & + & + & - & - & + & - & + \\
\hline & Leptophlebiidae & + & + & + & + & + & + & + & + & + & + & + & + & + & + & + & + & - & + & + & + \\
\hline Plecoptera & Notonemouridae & + & + & + & + & - & - & + & + & + & + & - & - & - & + & + & - & - & + & + & + \\
\hline \multirow[t]{10}{*}{ Trichoptera } & Calamoceratidae & - & - & - & + & + & - & - & - & - & + & - & - & - & - & - & - & - & - & - & + \\
\hline & Goeridae & + & - & - & - & - & - & + & - & - & + & - & - & - & - & - & - & - & - & - & + \\
\hline & Helicopsychidae & + & - & + & - & + & - & - & - & - & + & + & - & + & - & - & - & + & - & - & - \\
\hline & Hydroptilidae & + & - & - & - & + & + & & + & + & + & - & - & + & + & - & - & + & + & + & + \\
\hline & Hydropsychidae & + & + & + & + & + & + & + & + & + & + & + & + & + & + & + & + & + & + & + & + \\
\hline & Leptoceridae & + & + & + & + & + & + & + & + & & + & - & - & - & - & - & - & - & - & - & - \\
\hline & Odontoceridae & - & - & + & + & & + & + & + & + & + & - & - & - & + & - & - & - & + & + & + \\
\hline & Philopotamidae & - & - & - & + & - & - & + & + & - & + & - & - & + & - & - & - & + & - & - & + \\
\hline & Psychomyiidae & - & - & - & - & - & - & - & - & - & - & - & - & - & - & - & - & - & - & - & \\
\hline & Rhycophilidae & - & - & + & - & - & - & + & - & - & + & - & - & + & - & - & - & - & - & - & + \\
\hline \multirow[t]{5}{*}{ Odonata } & Aeshnidae & + & + & + & - & + & - & + & + & + & + & + & - & - & - & - & - & - & - & - & - \\
\hline & Synthemistidae & - & - & + & - & - & - & - & + & + & + & - & - & - & - & - & - & - & - & - & - \\
\hline & Lestidae & - & - & + & - & - & - & - & - & - & & - & - & - & - & - & - & - & - & - & - \\
\hline & Diphlebiidae & - & - & + & - & - & - & - & + & - & + & - & - & - & - & - & - & - & - & - & + \\
\hline & Coenagrionidae & - & - & - & - & - & - & - & - & - & - & - & - & - & - & - & - & - & - & - & + \\
\hline \multirow[t]{3}{*}{ Coleoptera } & Elmidae & + & - & + & + & + & + & + & - & + & + & + & - & + & + & & & + & + & + & + \\
\hline & Psephenidae & + & - & + & + & + & - & + & + & + & + & - & - & + & + & + & + & + & - & + & + \\
\hline & Gyrinidae & + & - & - & + & - & - & - & + & + & + & - & - & - & + & - & - & + & + & & + \\
\hline \multirow[t]{8}{*}{ Diptera } & Chironomidae & + & + & - & + & + & + & + & + & + & + & + & + & + & + & + & + & + & + & + & + \\
\hline & Culicidae & + & - & + & + & - & - & + & + & + & + & - & - & - & - & - & - & - & - & - & - \\
\hline & Psychodidae & + & + & + & + & + & + & + & - & + & + & + & - & + & + & + & - & + & + & + & + \\
\hline & Scymyidae & - & - & - & - & - & - & - & - & + & + & - & - & - & - & - & - & - & - & - & - \\
\hline & Simuliidae & + & - & + & + & - & - & + & + & + & + & + & - & + & + & + & - & + & + & + & - \\
\hline & Stratiomyidae & - & + & + & - & - & - & - & - & - & - & - & - & - & - & - & - & - & - & - & - \\
\hline & Tabanidae & - & - & - & - & + & - & - & - & + & + & - & - & - & - & - & - & - & - & - & + \\
\hline & Tipulidae & - & - & + & + & & + & + & & + & + & + & - & + & - & - & - & + & + & + & + \\
\hline Hirudinae & Rhynchobdelle & + & + & + & + & + & + & - & + & - & + & - & - & - & - & - & - & + & - & - & - \\
\hline Oligochaeta & Lumbricidae & + & - & + & - & - & - & + & - & + & + & - & - & - & - & - & - & - & - & - & - \\
\hline \multirow[t]{2}{*}{ Decapoda } & Potamonidae & - & - & - & - & + & - & - & - & - & - & - & - & + & - & - & - & - & - & - & + \\
\hline & Atyidae & - & - & - & - & - & - & - & - & + & + & - & - & - & - & - & - & - & - & - & - \\
\hline \multirow[t]{2}{*}{ Sorbeoconcha } & Paludomidae & + & + & + & + & - & - & + & - & - & + & + & + & + & - & - & - & + & + & + & + \\
\hline & Pilidae & - & - & + & - & - & - & - & - & - & + & - & - & - & - & - & - & - & - & - & - \\
\hline Neotaenioglossa & Thiarinae & + & - & + & + & + & + & + & - & - & + & - & - & - & - & - & + & - & - & - & + \\
\hline Hygrophila & Planobidae & - & - & + & - & - & - & - & - & - & - & - & - & - & - & - & - & - & - & - & - \\
\hline
\end{tabular}


Among the physical attributes tested, channel physical habitat quality index (CQI) reflects the habitat diversity within the channels. Improved habitat diversity within channels support diverse communities and increase the species richness (Barbour et al., 1999). In the present study CQI varied from 3.1 to 18 among the sites. High CQI values were recorded in sites associated with high forest cover and low CQI values resulted in sites associated with low forest cover. This suggests that local riparian vegetation has a strong impact on structuring stream channel features. Among the various functions of the riparian zone on structuring channel features, riparian canopy contributes to channel shade (Davies-Colley \& Rutherford, 2005). Wood recruitment in riparian forests determines the amount of large woody debris in the river channel and plays an important role in determining

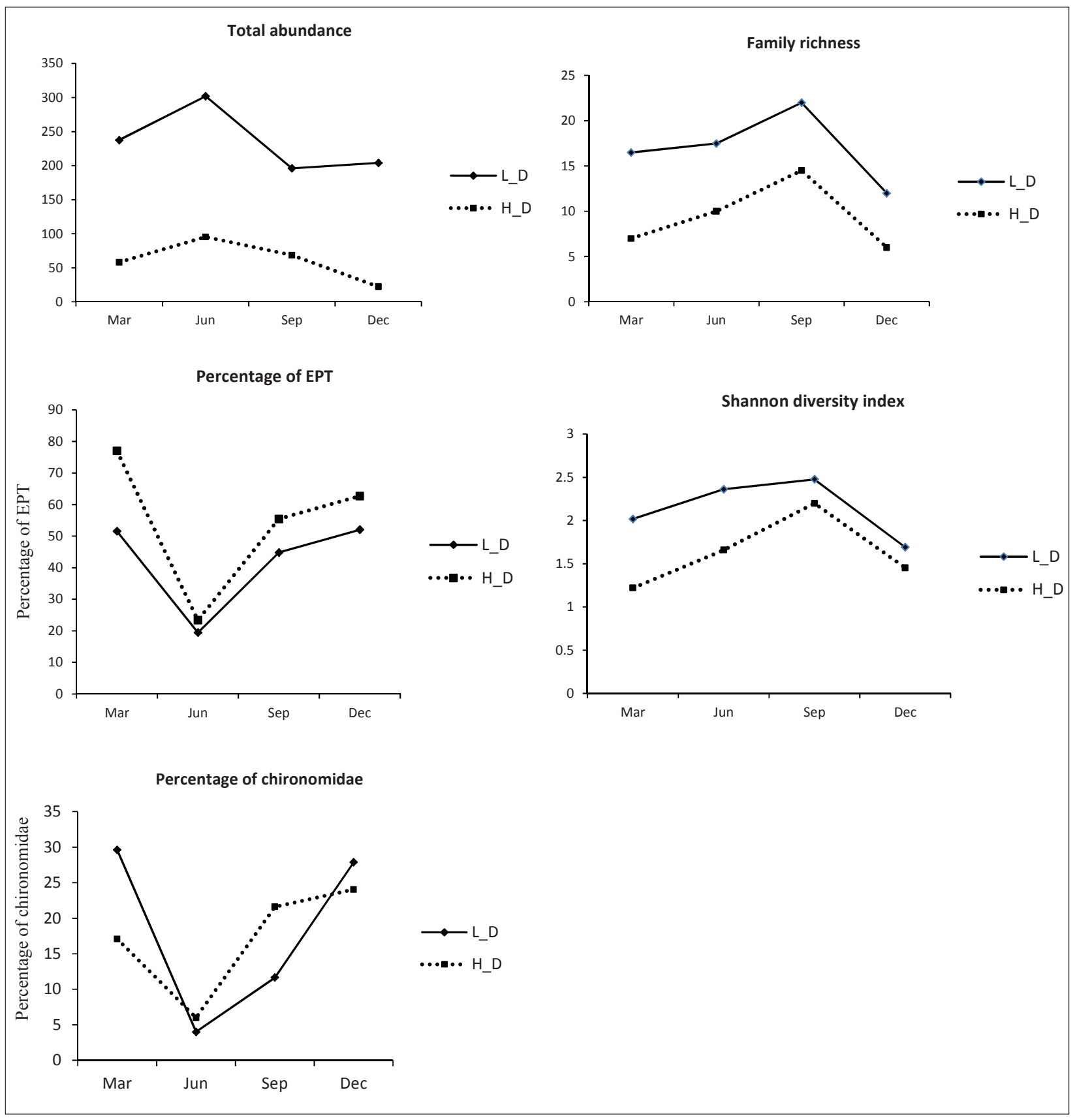

Figure 4: Variation of macroinvertebrate indices in sites associated with high (H_D) and low (L_D) catchment disturbances at entire catchment area 


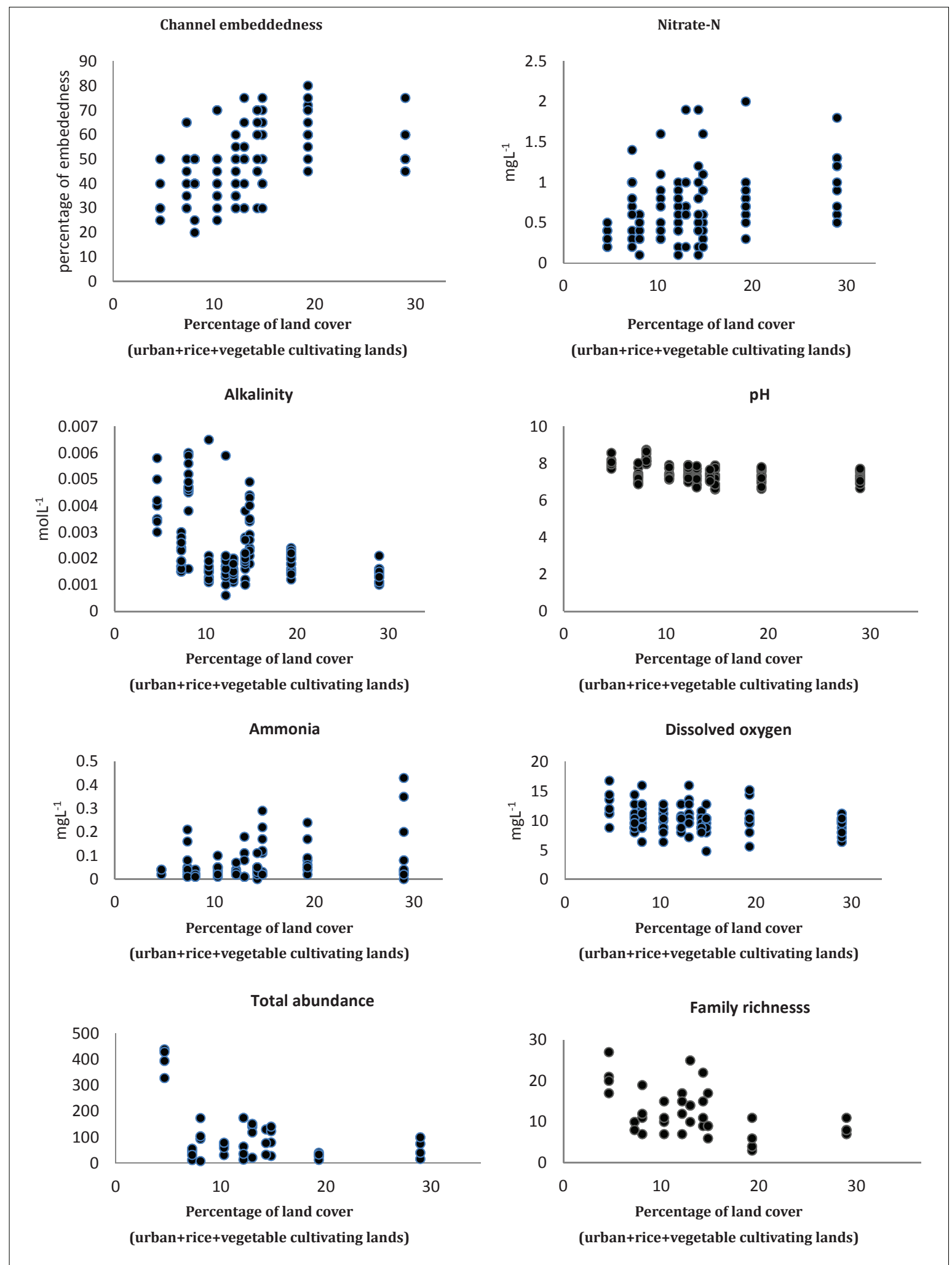

Figure 5: The variation of stream physical habitat, water quality and some macroinvertebrate indices with level of disturbance of micro catchments (as measured by the percentage of urban + rice and vegetable cultivating land cover in micro catchments) 
meso-habitat sequences (Brooks et al., 2003), velocity patterns, substrate composition and in-stream habitat heterogeneity (Elosegi et al., 2010). Embeddedness reflects the degree to which larger particles (e.g., boulder, rubble, gravel) in the stream bed are surrounded or covered by fine sediments (Platts et al., 1983; Fitzpatrick et al., 1998). The results clearly demonstrated that stream embeddedness significantly varied in sites associated with high level of catchment disturbances, and with the season (Table 3 ). The results suggest that stream channels in sites with disturbed landscapes are highly embedded by fine sediments than the reference sites (Figures 3 and 5). It is possible that the high input of soil particles from landscapes disturbed by vegetable cultivation and urban settlements in the given catchment may have contributed to the observed differences.

\section{Macroinvertebrate bioindicators}

During the study a total of 38 benthic macroinvertebrate families were recorded in the Badulu Oya catchment (Table 4). PCA and the results of two-way ANOVA indicated the factors contributing to the variation of macroinvertebrate indices in the sampling sites. Among the macroinvertebrate indices that were tested, total abundances and family richness were significantly influenced by the degree of catchment disturbance (Table 3; Figures 2 and 5). Macroinvertebrate total abundance and richness decreased with increasing catchment disturbances (Figures 4 and 5). As reflected in the PCA, improved water quality along with improved habitat quality (as reflected by CQI) has higher association with macroinvertebrate indices such as family richness and total abundance. It has been reported by many authors that stream features such as substratum characteristics and flow regimes interact with thermal regime generate habitat templates upon which macroinvertebrate assemblages are structured (Southwood, 1977; Poff \& Ward, 1990), which would be the case for the trends observed in the present study. However, other bioindices measured in the present study, i.e. percentage ETP taxa and percentage chironomidae, did not show significant association with catchment disturbance as depicted in the results of ANOVA test. However, in the PCA chironomidae percentage was associated with degraded catchments. This suggests that those indices need to be further tested for their application in the local context. The results of the present study also suggest that catchment scale land use activities in the Badulu Oya catchment influence the stream habitat features and water quality, ultimately determining the macroinvertebrate assemblage structure.

The present study shows that catchment disturbance through agriculture and urban activities also affect the functional feeding groups of macroinvertebrates. The functional feeding categories of biota in the streams are a better indicator of the energy dynamics within the streams as described in the river continuum concept (Vannote et al., 1980). The results of the present study indicated

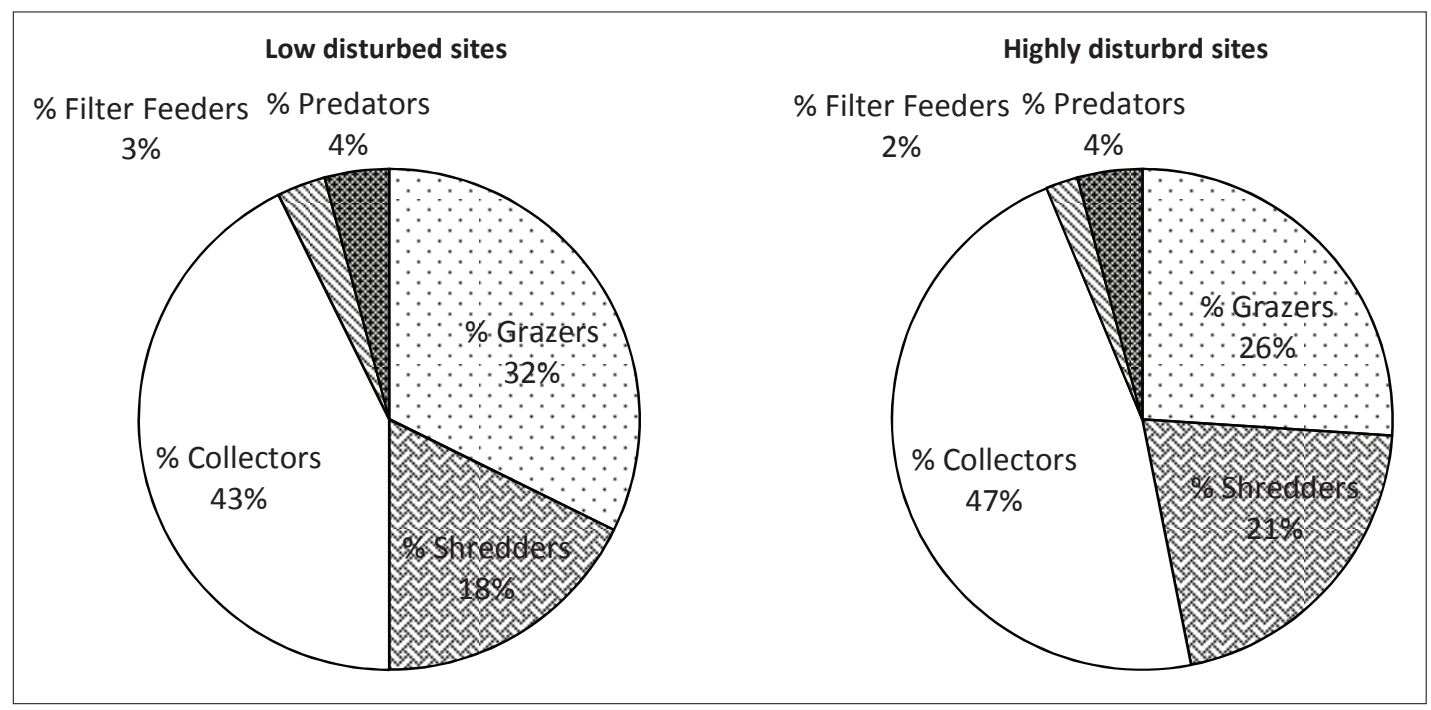

Figure 6: Variation of macroinvertebrate feeding groups in sites associated with high (H_D) and low (L_D) catchment disturbances at entire catchment area 
that the sites, which are impacted by land disturbance in the adjacent catchments are mostly dominated by collectors (Figure 6). The sites which are less affected by disturbance were dominated by grazers (Figure 6). It can be expected that the high level of fine particles coupled with increased levels of organic sediments entering the streams in disturbed sites may have contributed to increased number of collector gatherers in the impacted sites.

Overall the findings of the present study clearly indicate that catchment disturbance impacts by land use changes exert on stream ecological health of the Badulu Oya catchment.

\section{CONCLUSION}

In conclusion the findings of the present study suggest that land use activities in the Badulu Oya catchment significantly affects the ecological health of the stream. Chemical water quality variables such as EC, TS, TDS, $\mathrm{DO}$, alkalinity and $\mathrm{NO}_{3}-\mathrm{N}$; physical variables such as stream CQI and RQI indices; biological variables such as faecal coliform counts, macroinvertebrate indices like total abundance and family richness were significantly influenced by the degree of catchment disturbances. This suggests that there is a possibility to incorporate such variables in river health monitoring programmes in the given catchment.

However, many of the water quality monitoring programmes in Sri Lanka mainly focus on onsite water quality analysis to estimate the level of pollution. The present approach is important for accurate assessment of stream ecological health since it incorporated diverse attributes to assess the stream health. Lack of baseline data on biological indices to measure stream health in Sri Lanka makes this approach even more important for further development of bioindices and their application in river health monitoring programmes in Sri Lanka.

\section{Acknowledgement}

Authors acknowledge the National Research Council of Sri Lanka (Grant No. 13-160) for funding the research.

\section{REFERENCES}

1. Aguiar F.C. \& Ferreira M.T. (2005). Human-disturbed landscapes: effects on composition and integrity of riparian woody vegetation in the Tagus River basin, Portugal. Environmental Conservation 32: $30-41$.
DOI: https://doi.org/10.1017/S0376892905001992

2. Alam K., Rolfe J. \& Donaghy P. (2006). Economic and social impact assessment of water quality improvement. Australasian Journal of Regional Studies 12(1): 85 - 102.

3. Allan J.D. (1995). Stream Ecology: Structure and Function of Running Waters, pp. 388. Kluwer Academic Publishers, Dordrecht, The Netherlands.

DOI: https://doi.org/10.1007/978-94-011-0729-7

4. Amarathunga A.A.D., Weerasekara K.A.W.S., Sureshkumar N., Azmy S.A.M., Wickramaarchchi W.D.N. \& Kazama F. (2013). Behavior and loading of suspended sediment and nutrients from river basins in the hilly catena under intensive agriculture cropping: a case study in Upper Kotmale basin in Sri Lanka. Journal of Environmental Professionals Sri Lanka 2(2): 13 - 31.

DOI: https://doi.org/10.4038/jepsl.v2i2.6327

5. American Public Health Association (APHA) (2005). Standard Methods, $21^{\text {st }}$ edition. American Public Health Association, Washington DC, USA.

6. Bandara D. \& Thiruchelvam S. (2008). Factors affecting the choice of soil conservation practices adopted by potato farmers in Nuwara Eliya district, Sri Lanka. Tropical Agricultural Research and Extension 11: 49 - 54.

DOI: https://doi.org/10.4038/tare.v11i0.1789

7. Barbour M.T., Gerritsen J., Snyder B.D. \& Stribling J.B. (1999). Rapid Bioassessment Protocols for Use in Streams and Wadeable Rivers: Periphyton, Benthic Macroinveretebrates and Fish, $2^{\text {nd }}$ edition. US Environmental Protection Agency, Office of Water, Washington DC, USA.

8. Beschta R.L. \& Taylor R.L. (1988). Stream temperature increases and land use in a forested Oregon watershed. Water Resources Bulletin 24: 19 - 24.

DOI: https://doi.org/10.1111/j.1752-1688.1988.tb00875.x

9. Brooks A.P., Brierley G.J. \& Miller R.G. (2003). The longterm control of vegetation and woody debris on channel and flood-plain evolution: insights from a paired catchment study in southeastern Australia. Geomorphology 51: 7 - 29.

10. Bunn S., Edward D. \& Loneragan N. (1986). Spatial and temporal variation in the macroinvertebrate fauna of streams of the northern Jarrah forest, Western Australia: community structure. Freshwater Biology 16(1): 67 - 91. DOI: https://doi.org/10.1111/j.1365-2427.1986.tb00949.x

11. Central Environmental Authority (CEA) (2001). Proposed Ambient Water quality Standards for Inland Waters Sri Lanka. Central Environmental Authority, Battaramulla, Sri Lanka.

12. Changnon S.A. \& Demissie M. (1996). Detection of changes in stream flow and floods resulting from climate fluctuations and land use-drainage changes. Climatic Change 32(4): 411 - 421.

DOI: https://doi.org/10.1007/BF00140354

13. Cooper C.M. (1987). Benthos in Bear Creek, Mississippi: effects of habitat variation and agricultural sediments. Journal of Freshwater Ecology 4: 101 - 114. DOI: https://doi.org/10.1080/02705060.1987.9665167

14. Commonwealth Scientific and Industrial Research Organisation (CSIRO) (1999). Interactive Guide to 
Australian Aquatic Invertebrates, CD ROM, $2^{\text {nd }}$ edition. CSIRO Publishing, Australia.

15. Cranston P. (1996). Identification Guide to the Chironomidae of New South Wales. AWT Identification Guide Number 1. Australian Water Technologies Pty. Ltd., West Ryde, Sydney, Australia.

16. Davies-Coolley R.J. \& Rutherford J.C. (2005). Some approaches for measuring and modeling riparian shade. Ecological Engineering 24: 525 - 530.

DOI: https://doi.org/10.1016/j.ecoleng.2004.01.006

17. De Alwis K.A. \& Panabokke C.R. (1972) Hand-book of soils of Sri Lanka (Ceylon). Journal of the Soil Science Society of Ceylon 2: 1 - 97.

18. Dean J.C. \& Suter P.J. (1996). Mayfly Nymphs of Australia: A Guide to Genera. Identification Guide No. 7. Co-operate Research Centre for Freshwater Ecology, Ellis Street, Thurgoona, Albury, Australia.

19. Death R.G. \& Winterbourn M.J. (1995). Diversity patterns in stream benthic invertebrate communities: the influence of habitat stability. Ecology 76: 1446 - 1460.

DOI: https://doi.org/10.2307/1938147

20. Dharmarathne S., Silva E.I.L. \& Athukorale N. (2008). Water quality of riverine and lacustrine habitats of Mahaweli River from headwaters to downstream. International Scientific Workshop on Riverscapes in Sri Lanka: Current Knowledge and Future Challenges, Sri Lanka Foundation Institute, Colombo, pp. 21.

21. Ecology's Water Quality Program (2005). Focus on Faecal Coliform Bacteria. Available at: https://fortress.wa.gov/ ecy/publications/documents/0210010.pdf. Accessed December 2005.

22. Elosegi A.J., D'iez R. \& Mutz M. (2010). Effects of hydromorphological integrity on biodiversity and functioning of river ecosystems. Hydrobiologia 657: 199 -215 .

DOI: https://doi.org/10.1007/s10750-009-0083-4

23. Fitzpatrick F.A., Scudder B.C., Lenz B.N. \& Sullivan D.J. (1998). Revised Methods for Characterizing Stream Habitat in the National Water-Quality Assessment Program, Water-Resources Investigations Report, pp. 98 4052. US Geological Survey, Raleigh, USA.

24. Gooderham J. \& Tsyrlin E. (2002). The Waterbug Book: a Guide to the Freshwater Macroinvertebrates of Temperate Australia. CSIRO Publishing, Australia.

25. Gunawardena E.R.N., Maheesh M.T.M., Gunawardana I.P.P., Rathnapriya E.A.S.K., Amarasekara N.G.T.S. \& Thrikawala S. (2010). Effects of socioeconomic and political factors in solid waste generation and water pollution. Symposium Proceedings of the Water Professional's Day, Crossing Boundaries Project. Post Graduate Institute of Agriculture and Geo-informatics Society of Sri Lanka.

26. Gregory M.B. \& Fric E.A. (2000). Faecal-Coliform Bacteria Concentrations in Streams of the Chattahoochee River National Recreation Area, Metropolitan Atlanta, Georgia, Water-Resources Investigations Report 00-4139. US Geological Survey, Raleigh, USA.

27. Gregory S.V., Swanson F.J., McKee W.A. \& Cummins K.W. (1991). An ecosystem perspective of riparian zones. Bioscience 41: 540 - 551 .
DOI: https://doi.org/10.2307/1311607

28. Hauer F.R. \& Lamberti G.A. (1996). Methods in Stream Ecology. Academic Press, San Diego, California, USA.

29. Hewawasam T. (2010). Effect of land use in the upper Mahaweli catchment area on erosion, landslides and siltation in hydropower reservoirs of Sri Lanka. Journal of the National Science Foundation of Sri Lanka 38(1): 3 - 14. DOI: https://doi.org/10.4038/jnsfsr.v38i1.1721

30. Hilsenhoff W.L. (1987). An improved biotic index of organic stream pollution. The Great Lakes Entomologist 20(1): $31-40$.

31. Jayawardana J.M.C.K. \& Westbrooke M. (2010). Potential effects of riparian vegetation changes on functional organization of macroinvertebrates in central Victorian streams. The Victorian Naturalist 12: $36-48$.

32. Jayawardana J.M.C.K., Westbrooke M. \& Wilson M. (2010). Leaf litter decomposition and utilization by macroinvertebrates in a central Victorian River in Australia. The Victorian Naturalist 127(4): 93 - 106.

33. Jayawardana J.M.C.K., Westbrooke M,. Wilson M. \& Hurst C. (2006a). Macroinvertebrate communities in willow (Salix spp.) and reed beds (Phragmites australis) in central Victorian streams in Australia. Marine and Freshwater Research 57(4): 429 - 439.

DOI: https://doi.org/10.1071/MF05139

34. Jayawardana J.M.C.K., Westbrooke M., Wilson M. \& Hurst C. (2006b). Macroinvertebrate communities in Phragmites australis (Cav.) Trin. ex Steud. reed beds and open bank habitats in central Victorian streams in Australia. Hydrobiologia 568(1): $169-185$.

DOI: https://doi.org/10.1007/s10750-006-0103-6

35. Jayawardana J.M.C.K., Jayathunga T.R. \& Edirisinghe E.A. (2016). Water quality of Nilwala River, Sri Lanka in relation to land use practices. Sri Lanka Journal of Aquatic Sciences 21(2): $77-94$. DOI: https://doi.org/10.4038/sljas.v21i2.7504

36. Johnson R.K., Wiederholm T. \& Rosenberg D.M. (1993). Freshwater biomonitoring using individual organisms, populations, and species assemblages of benthic macroinvertebrates. Freshwater Bio Monitoring and Benthic Macroinvertebrates (eds. D.M. Rosenberg \& V.H. Resh), pp. 40 - 158. Chapman and Hall, New York, USA.

37. Johnson L.B., Richards C., Host G. \& Arthur J.W. (1997). Landscape influences on water chemistry in Midwest stream ecosystems. Freshwater Biology 37: 193 - 208. DOI: https://doi.org/10.1046/j.1365-2427.1997.d01-539.x

38. Karr J.R. \& Chu E.W. (1999). Restoring Life in Running Waters: Better Biological Monitoring. Island Press, Washington DC, USA.

39. Lake P., Barmuta L., Boulton A., Campbell I. \& St Clair R. (1985). Australian streams and Northern Hemisphere stream ecology: comparisons and problems. Proceedings of the Ecological Society of Australia 14: 61 - 82.

40. Lenat D.R. (1993). A biotic index for the southeastern United States: derivation and list of tolerance values, with criteria for assigning water-quality ratings. Journal of the North American Benthological Society 12: 279 - 290.

DOI: https://doi.org/10.2307/1467463

41. Lencioni V., Marziali L. \& Rossaro B. (2012). Chironomids 
as bioindicators of environmental quality in mountain springs. Freshwater Science 31(2): 525 - 541.

DOI: https://doi.org/10.1899/11-038.1

42. Mazlum N., Özer A. \& Mazlum S. (1999). Interpretation of water quality data by principal components analysis. Turkish Journal of Engineering and Environmental Sciences 23(1): 19 - 26.

43. Mendis A.S. \& Fernando C.H. (2002). A guide to the freshwater fauna of Ceylon. Sri Lanka Freshwater Fauna and Fisheries (eds. C.H. Fernando \& S.R. Weerwardhena). Cambridge University Press, Cambridge, UK.

44. Merritt R.W., Cummins K.W. \& Burton T.M. (1984). The role of aquatic insects in the processing and cycling of nutrients. The Ecology of Aquatic Insects (eds. V.H. Resh \& D.M. Rosenberg). Praeger Scientific, New York, USA.

45. Muirhead-Thomson R.C. (1987). Pesticide Impact on Stream Fauna: With Special Reference to Macroinvertebrates. Cambridge University Press, Cambridge, UK. DOI: https://doi.org/10.1017/CBO9780511898303

46. Omernik J.M. (1977). Nonpoint Source-Stream Nutrient Level Relationships: A Nationwide Study. US EPA - 600/377-105. US Environmental Protection Agency, Washington DC, USA.

47. Pinder A.M. \& Brinkhurst R.O. (1994). A Preliminary Guide to the Identification of the Microdrile Ologochaeta of Australian Inland Water. Identification Guide No. 1. Co-operative Research Centre for Freshwater Ecology (CRCFE), Albury, NSW, Australia.

48. Plafkin J.L., Barbour M.T., Porter K.D., Gross S.K. \& Hughes R.M. (1989). Rapid Bio Assessment Protocols for Use in Streams and Rivers: Benthic Macroinvertebrates and Fish. EPA/444/4-89-001. US Environmental Protection Agency, Wahington DC, USA.

49. Platts W.S., Megahan W.F. \& Minshall W.G. (1983). Methods for Evaluating Stream, Riparian, and Biotic Conditions. General Technical Report INT-138. USDA Forest Service, Rocky Mountain Research Station, Ogden, Utah, USA.

DOI: https://doi.org/10.2737/INT-GTR-138

50. Poff N.L. \& Ward J. (1990). Physical habitat template of lotic systems: recovery in the context of historical pattern of spatiotemporal heterogeneity. Environmental Management 14(5): 629 .

DOI: https://doi.org/10.1007/BF02394714

51. Rutherford J.C., Blackett S., Blackett C., Saito L. \& DaviesColley R.J. (1997). Predicting the effects of shade on water temperature in small streams. New Zealand Journal of Marine and Freshwater Research 31(5): 707 - 721. DOI: https://doi.org/10.1080/00288330.1997.9516801

52. Smith J.L.M. (1996). Biological water quality assessment of rivers: use of macroinvertebrate communities. The Rivers Handbook. Hydrological and Ecological Principles (eds. P. Calow \& G.E. Petts), pp. 144 - 170. Blackwell Science Ltd., Oxford, UK.

53. Southwood T. (1977). Habitat, the template for ecological strategies. The Journal of Animal Ecology 46: 337 - 365. DOI: https://doi.org/10.2307/3817

54. Sponseller R., Benfield E. \& Valett H. (2001). Relationships between land use, spatial scale and stream macroinvertebrate communities. Freshwater Biology 46(10): 1409 - 1424. DOI: https://doi.org/10.1046/j.1365-2427.2001.00758.x

55. Tánago M.G. \& Jalón D.G. (2011). Riparian quality index (RQI): a methodology for characterizing and assessing the environmental conditions of riparian zones. Limnetica 30(2): $235-254$.

56. US Environmental Protection Agency (USEPA) (1978). Microbiological Methods for Monitoring the EnvironmentWater and Waste, pp. 17 - 101. US Environmental Protection Agency, Office of Water, Washington DC, USA.

57. Vannote R.L., Minshali G.W., Cummins K.W., Sedell J.R. \& Cushing C.E. (1980). The river continuum concept. Canadian Journal of Fish and Aquatic Sciences 37: $130-137$.

DOI: https://doi.org/10.1139/f80-017

58. Wallace J.B., Grubaugh J.W. \& Whiles M.R. (1996). Biotic indices and stream ecosystem processes: results from an experimental study. Ecological Applications 6(1): $140-151$.

DOI: https://doi.org/10.2307/2269560

59. Watawala R.C., Liyanage J.A. \& Mallawatantri A. (2010). Assessment of risks to water bodies due to residues of agricultural fungicide in intensive farming areas in the upcountry of Sri Lanka using an indicator model. Proceedings of the National Conference on Water, Food Security and Climate Change in Sri Lanka (eds. A. Evans \& K. Jinapala), International Water Management Institute, Colombo, Sri Lanka, pp. $69-76$.

60. Waters T.F. (1995). Sediment in Streams: Sources, Biological Effects and Control. American Fisheries Society Monograph 7. American Fisheries Society, Bethesda, Maryland, USA.

61. Webster J.R., Gurtz M.E., Hains J.J., Meyer J.L,. Swank W.T., Waide J.B. \& Wallace J.B. (1983). Stability of stream ecosystems. Stream Ecology (eds. J.B. Barnes \& G.W. Minshall), pp. 355 - 394. Plenum Press, New York, USA. DOI: https://doi.org/10.1007/978-1-4613-3775-1_14

62. Wickramagamage P. (1998). Large-scale deforestation for plantation agriculture in the hill country of Sri Lanka and its impact. Hydrological Processes 12(13 - 14): 2015 2028. 